\title{
A CONTRIBUIÇÃO DAS ATIVIDADES AGRÍCOLAS E NÃO-AGRÍCOLAS PARA A DESIGUALDADE DE RENDA NO BRASIL RURAL*
}

\author{
Marlon Gomes Ney ${ }^{\S}$ \\ Rodolfo Hoffmann ${ }^{\text {a }}$
}

\begin{abstract}
RESUMO
O trabalho analisa a contribuição das atividades agrícolas e não-agrícolas para a desigualdade de renda rural, observando dois indícios: sua participação no rendimento total dos domić́lios em diferentes estratos de renda delimitados por percentis e a decomposição do índice de Gini. Além da população oficialmente rural do País, a pesquisa abrange as chamadas "cidades rurais", compostas por áreas que, mesmo oficialmente consideradas urbanas, apresentam baixo contingente populacional e densidade demográfica. Os resultados obtidos revelam que as ocupações agrícolas e não-agrícolas contribuem, respectivamente, para a redução e para o aumento das disparidades de rendimentos no meio rural brasileiro.
\end{abstract}

Palavras-chave: desigualdade, distribuição de renda, meio rural.

\begin{abstract}
This study analyses the contribution of agricultural and non-farm activities to the inequality of rural income distribution in Brazil, observing two evidences: the participation of each sector in the household earnings of different income strata delimited by percentiles and the decomposition of Gini coefficients. Besides the official rural population, this research includes towns whose population and demographic density are very low. The results show that agriculture and rural non-farm activities contribute, respectively, to reduce and to increase rural income inequalities in Brazil.
\end{abstract}

Keywords: inequality, income distribution, rural areas, Brazil.

JEL classification: D31, Q15, R11.

* A pesquisa contou com apoio financeiro da FAPESP e do CNPq.

$\S$ Professor do Centro de Ciências do Homem da UENF. Endereço para contato: Rua Tenente-Coronel Cardoso, n. 873, bl. 03, ap. 203 - CEP: 28035-042 - Campos dos Goytacazes - RJ. E-mail: marlonney@uenf.br.

a Professor do Instituto de Economia da UNICAMP. Endereço para contato: Rua Bernardino de Campos, 620, ap. 61 CEP: 13419-100 - Piracicaba - SP. E-mail: rhoffman@esalq.usp.br.

Recebido em abril de 2007. Aceito para publicação em maio de 2008. 


\section{INTRODUÇÃO}

A expansão das atividades rurais não-agrícolas (RNA) é um componente importante da atual fase de desenvolvimento da economia rural. Ela tem criado novas oportunidades de trabalho para a população residente no campo e alternativas de se obter ganhos superiores aos das atividades agrícolas, constituindo parcela crescente da renda rural. Esse fenômeno, embora mais pesquisado em países desenvolvidos, também pode ser facilmente observado em países em desenvolvimento (REARDON, 1999; LANJOUW, 1999).

Uma questão bastante discutida na literatura internacional sobre a expansão das atividades RNA é o seu efeito na desigualdade de renda e na pobreza rural nos países subdesenvolvidos. Quanto à pobreza, estudos comprovam que as atividades industriais e de serviços representam uma parcela significativa do emprego e do rendimento das famílias rurais pobres. Na sua ausência, a magnitude da pobreza seria substancialmente maior (REARDON et alii, 1998; LANJOUW, 1999). Porém, no que se refere à desigualdade, o desenvolvimento eqüitativo das atividades RNA em muitos casos não acontece.

De acordo com Reardon et alii (1998), embora as famílias pobres tenham necessidade de ascender a ocupações remuneradas fora do setor primário para superar sua condição de pobreza, sua capacidade de ascensão fica bastante restrita aos trabalhos casuais, de baixa qualificação e mal remunerados. O motivo é a carência de ativos como capital inicial e educação, necessários principalmente para se alcançar as atividades mais produtivas e de maior rentabilidade. As famílias mais ricas, ao contrário, como têm uma mão-de-obra qualificada e recursos financeiros, podem se dedicar às ocupações mais rentáveis. As atividades não-agrícolas, assim, tanto podem contribuir para reduzir a concentração da renda rural quanto para aumentá-la, dependendo da sua participação na renda total da população relativamente pobre e rica.

Diante de tal possibilidade, nosso trabalho pretende estudar a contribuição das ocupações não-agrícolas para a desigualdade na distribuição da renda domiciliar per capita rural. A análise basear-se-á na participação dessas atividades no rendimento total dos domicílios em diferentes estratos de renda domiciliar per capita delimitados por percentis e na decomposição do índice de Gini. Embora o objeto principal de nosso estudo sejam as ocupações RNA e agrícolas, serão ainda observadas as contribuições de outras fontes de rendimentos da população rural para a desigualdade, como, por exemplo, os ganhos provenientes de aposentadorias ou pensões, aluguéis e programas oficiais de renda mínima.

Na próxima seção, veremos que as ocupações não-agrícolas nem sempre contribuem para a redução das disparidades de renda nas áreas rurais de todos os países, porque os mesmos fatores responsáveis pela concentração da renda na agricultura também tendem a gerar desigualdades nas atividades não-agrícolas. A Seção 3 define a base de dados utilizada na pesquisa. Nas quarta e quinta seções, analisaremos até que ponto as atividades RNA e agrícolas contribuem para aumentar ou reduzir a concentração da renda rural no País. 


\section{A PARTICIPAÇÃO DOS MAIS POBRES NAS ATIVIDADES RURAIS NÃO-AGRÍCOLAS}

De acordo com estudo de Reardon et alii (1998), a decisão de uma família rural de ingressar em algum tipo de atividade não-agrícola é função dos incentivos encontrados na atividade e de sua capacidade de ascensão. O modelo analisado pelos autores elabora uma função de incentivos e capacidades das famílias rurais, particularmente das mais pobres e das mais ricas, para descrever os paradoxos e desafios do fomento eqüitativo do setor RNA.

Os incentivos estão relacionados à renda, aos custos e aos riscos das atividades não-agrícolas e podem ser agregados em dois grupos: a) fatores de "atração”, especialmente a possibilidade de se obter rendimentos mais altos e estáveis do que nos empregos agrícolas sazonais e nas pequenas plantações; b) fatores de "expulsão", quando a diversificação das atividades das famílias agrícolas em direção às atividades industriais e de serviços representa uma estratégia para amenizar problemas com a insuficiência de renda obtida com a agricultura provocada pela escassez de terra para plantar, pela sazonalidade das colheitas e pelos prejuízos causados por secas, inundações e pragas nas plantações, que tornam muito vulneráveis os rendimentos gerados no setor primário.

Embora uma família rural possa ter fortes incentivos para ascender às ocupações nãoagrícolas, sua capacidade de ascensão pode ser bastante limitada pela escassez de ativos como: a) educação, variável importante para a implantação de atividades de processamento e comercialização de alimentos dentro de empreendimentos que antes só produziam bens primários, para o sucesso dos empreendimentos não-agrícolas e para a obtenção de empregos com maiores salários; b) conhecimentos e habilidades específicas, tais como habilidade na costura e no serviço de pedreiro, que permitem o acesso a oportunidades de trabalho fora do setor primário; c) formas de riquezas liquidáveis como a terra, que possam servir como garantia de empréstimos e, por isso, são importantes para o acesso ao crédito para ser investido não só na agricultura como também em atividades industriais e de serviços.

Reardon et alii (1998, p. 7) destacam que, em cada família, ocorrem conflitos entre os incentivos e as capacidades dos moradores de ingressar no setor não-agrícola, dando origem a um "paradoxo a nível micro". As famílias mais pobres e que sofrem com a escassez de terra para plantar têm grande necessidade de ascender às ocupações RNA por causa dos fatores de "expulsão", que aumentam sua necessidade de manejar riscos e limitações crônicas no nível de renda agrícola. No entanto, sua capacidade de ascensão é bastante limitada pela escassez de ativos como educação, conhecimentos específicos e propriedade de terra.

As famílias mais ricas, ao contrário, têm menor necessidade de ascender às ocupações RNA por fatores de "expulsão", mas sua capacidade de ascensão, porque possuem maiores níveis de escolaridade e área de terra, é maior do que a capacidade das famílias pobres. Elas ingressam nos setores industrial e de serviços principalmente por causa dos fatores de "atração", ou seja, pelos rendimentos mais atraentes em atividades que exigem maior volume de capital humano e físico. Enquanto os mais ricos podem assumir um pequeno comércio ou um trabalho assalaria- 
do qualificado, os pobres ficam com trabalhos que não exigem qualificação, seja como assalariado agrícola seja em serviços não-agrícolas de baixa remuneração e sazonais (KAGEYAMA; HOFFMANN, 2000).

Uma hipótese comum de ser encontrada na literatura é que o nível de renda não-agrícola das famílias rurais deve estar negativamente correlacionado com a posse de terra, porque as famílias que sofrem com a escassez de terra têm uma dependência maior do rendimento RNA se comparada à das famílias com grandes propriedades. No entanto, essa não é necessariamente a realidade encontrada nos países em desenvolvimento. Se, por um lado, a escassez de terra e a insuficiência de renda obtida no setor primário aumenta a necessidade de as famílias ascenderem às atividades RNA, por outro, limita sua capacidade de ascensão. As desigualdades "no acesso à terra também geram desigualdades de oportunidades no acesso ao emprego não-agrícola, porque a renda agrícola, o uso da terra como garantia de empréstimos e o poder político que a terra oferece podem afetar a participação nas atividades RNA.” (REARDON, 1999, p. 27).

A relação existente entre a participação da renda RNA no rendimento total da família e o tamanho da posse da terra, ou o nível de renda familiar, não é uniforme em todos os países subdesenvolvidos. Tanto existem evidências de relação linear negativa no Kenya e Índia, quanto de relação linear positiva na Nigéria e Ruanda, por exemplo. Entre os dois extremos, existem casos sem uma relação clara e até de relações em forma de "U”, e em forma de "U" invertido (ver Figura 1). Além disso, quando em vez da participação é analisada a relação entre nível de renda RNA e rendimento familiar ou posse da terra, a relação se torna positiva em um número maior de países, como no México, Argentina, Etiópia e Paquistão.

Figura 1 - Formas de relações entre participação (nível) da renda RNA e estratos de renda total ou posse da terra, no meio rural de alguns países em desenvolvimento

a) Kanzara, Índia, 1975/80

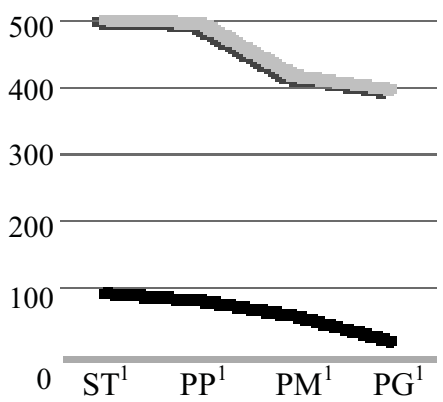

b) Kenya central, 1974-75

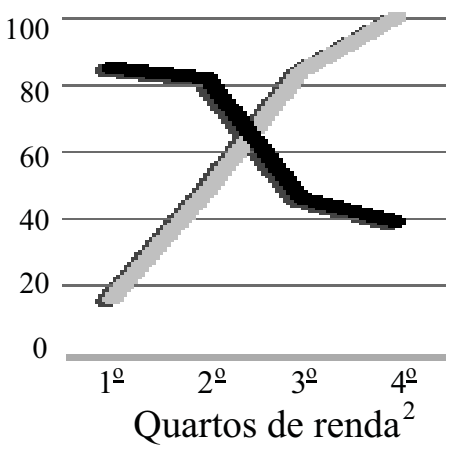

c) México, 1994

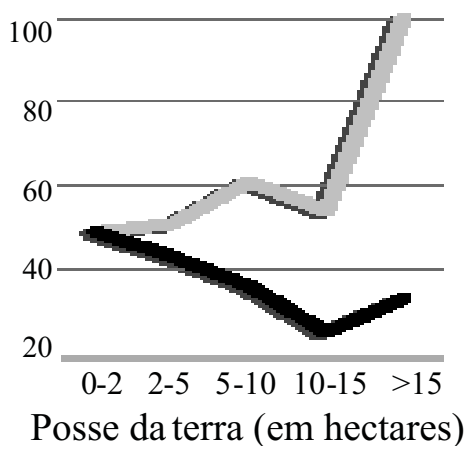


d) Nigéria, 1989/90

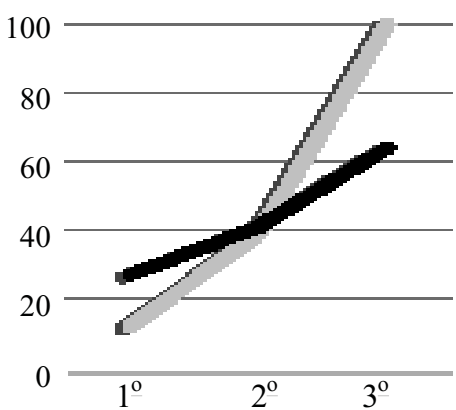

Terços de renda ${ }^{2}$

g) Argentina, 1996

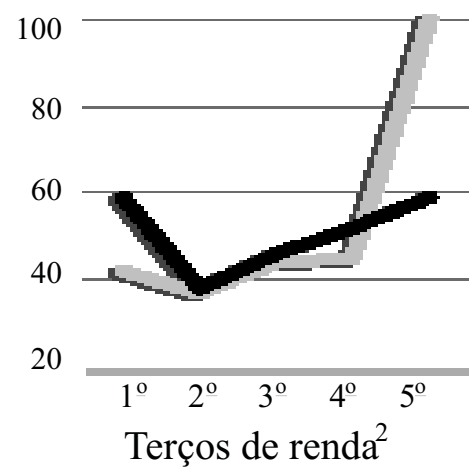

e) Ruanda, 1991

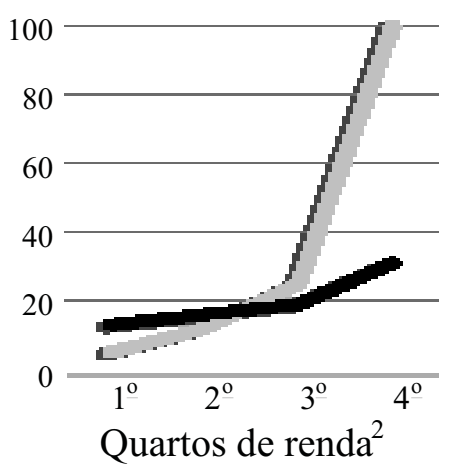

h) Attock, Paquistão, 1986/89

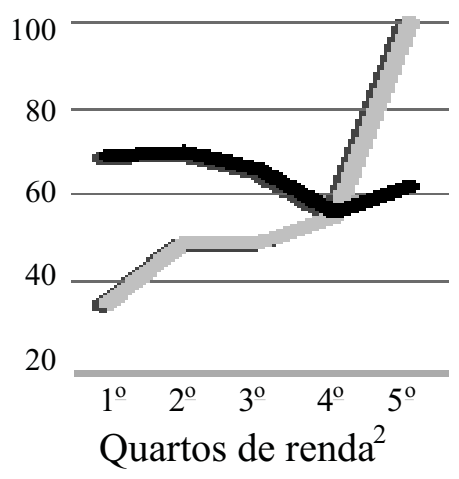

f) Moçambique 1991

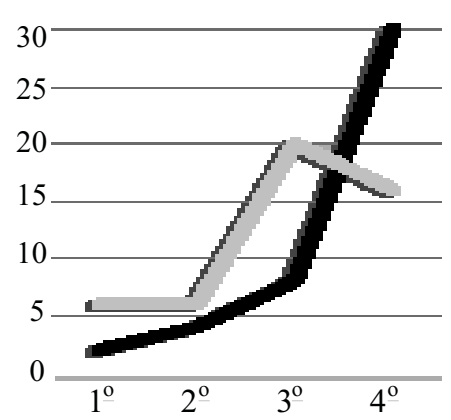

Quartos de renda ${ }^{2}$

i) Etiópia 1989/90

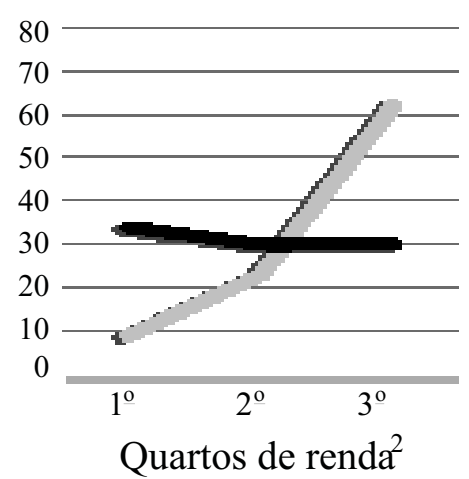

Participação da RNA

Nível de renda RNA

Notas: 1 As abreviações significam: ST - Trabalhadores Sem Terra; PP - Propriedade Pequena; PM - Propriedade Média; PG - Propriedade Grande. 2 Classificação da população rural em diferentes estratos de renda familiar delimitados por percentis.

Fonte: Reardon, 1999.

No Brasil, não encontramos nenhum estudo dessa natureza, o qual será realizado na Seção 4. De qualquer maneira, no momento vale destacar que o ponto de partida para explicar tamanha heterogeneidade entre países está nos diferentes tipos de atividades RNA adotadas pelas famílias rurais mais pobres e pelas mais ricas, ou pelas que sofrem o problema da escassez de terra e pelas que possuem grandes empresas agrícolas. E o tipo de atividade é fortemente determinado pelo nível educacional das pessoas.

Lanjouw (1999) destaca o fato de a elevação do nível geral de escolaridade da população rural, nos países em desenvolvimento, ser um fator crucial para a expansão das atividades RNA mais produtivas. Outros trabalhos mostram que o desempenho educacional é variável importante para a implantação de atividades de processamento e comercialização de alimentos dentro de empreendimentos que antes só produziam bens primários, para o sucesso dos empreendimentos não-agrícolas e para a obtenção de empregos com maiores salários (REARDON, 
1999). Pesquisas feitas na América Latina, por sua vez, coincidem em assinalar que apenas as pessoas com maiores níveis de escolaridade ascendem às ocupações RNA melhor remuneradas (BERDEGUÉ et alii, 2000). ${ }^{1}$ Os indivíduos com baixos níveis educacionais, particularmente os pobres, desempenham ocupações pouco rentáveis e casuais.

Além do "paradoxo a nível micro", resultado das diferenças entre o valor dos ativos das famílias mais pobres e mais ricas, existe o "paradoxo a nível meso" (REARDON et alii, 1998). Outro determinante importante da capacidade de ascensão das famílias às atividades nãoagrícolas é a localidade onde ela reside. A presença de pessoas qualificadas no domicílio para trabalhar na indústria ou no setor de serviços não é suficiente para a substituição de atividades agrícolas por não-agrícolas dentro da família. Se, por um lado, a mão-de-obra deve estar de preferência qualificada para o exercício de outras atividades fora do setor, por outro, a economia local deve ser dinâmica o suficiente para absorvê-la.

A dimensão do mercado consumidor de bens e serviços produzidos na localidade condiciona o nível de emprego e renda gerado em atividades RNA. A demanda pode advir da própria população rural ou de centros urbanos. As economias rurais mais ricas e dinâmicas são as que conseguem atrair grande número de consumidores para seus atributos territoriais e/ou destinar boa parte de sua produção, inclusive primária, para mercados diferenciados. A disponibilidade de boa infra-estrutura física e social na localidade, por sua vez, constitui condição fundamental para o desenvolvimento. Rodovias facilitam a venda de bens e serviços a um número maior de consumidores e a disponibilidade de escolas aumenta a capacidade de a população desempenhar atividades bem remuneradas fora da agricultura.

As dificuldades de as famílias pobres que vivem em localidades rurais com baixo nível de desenvolvimento ascenderem às ocupações não-agrícolas são particularmente graves no Brasil, onde as desigualdades inter-regionais são enormes e grande parte da pobreza está localizada na região Nordeste. De acordo com o estudo de Ferreira e Lanjouw (2000), por exemplo, 63\% de todos os pobres do País, em 1996, viviam nessa região, onde a incidência da pobreza é ainda mais severa no campo: quase a metade das 16,5 milhões de pessoas que moravam nas áreas rurais nordestinas, naquele ano, era pobre. As áreas pobres em recursos têm grande necessidade de expandir os empregos RNA para aliviar a pobreza, mas freqüentemente lhes faltam as fontes de demanda por bens e serviços não-agrícolas (motores do setor de atividades RNA) que elas poderiam produzir (ver Quadro 1).

1 Em Berdegué et alii (2000, p. 1): "emprego inclui tanto o trabalho de autônomo quanto o emprego assalariado". Traduzimos então "emprego RNA” como ocupação RNA. 


\section{Quadro 1 - Situações de desenvolvimento do emprego rural não-agrícola comuns nos países da América Latina}

\begin{tabular}{|c|c|c|}
\hline Vínculos & Motores & Exemplos \\
\hline I - Produção agrícola & $\begin{array}{l}\text { A produção agropecuária requer bens e } \\
\text { serviços não-agrícolas e atrai investimentos na } \\
\text { expansão da agroindústria local. }\end{array}$ & $\begin{array}{l}\text { Comércio de insumos } \\
\text { Serviços de transporte } \\
\text { Reparos mecânicos } \\
\text { Agroindústria }\end{array}$ \\
\hline II - Consumo da população rural & $\begin{array}{l}\text { A população rural demanda bens e serviços } \\
\text { produzidos dentro ou fora da localidade. }\end{array}$ & $\begin{array}{l}\text { Pequenos comércios } \\
\text { Serviços de costura } \\
\text { Transporte }\end{array}$ \\
\hline III - Serviços públicos & $\begin{array}{l}\text { Os serviços públicos no meio rural geram } \\
\text { empregos. }\end{array}$ & $\begin{array}{l}\text { Professores } \\
\text { Profissionais de saúde }\end{array}$ \\
\hline IV - Consumo da população urbana & $\begin{array}{l}\text { A população urbana demanda bens e serviços } \\
\text { que só podem ser produzidos no meio rural. }\end{array}$ & $\begin{array}{l}\text { Turismo de praia e campo } \\
\text { Artesanatos locais } \\
\text { Serviços domésticos } \\
\text { Construção civil }\end{array}$ \\
\hline V- Mercado de trabalho urbano & $\begin{array}{l}\text { Algumas pessoas moram no meio rural por } \\
\text { causa da qualidade de vida ou menor custo de } \\
\text { moradia, mas trabalham em áreas urbanas. }\end{array}$ & $\begin{array}{l}\text { Construção civil } \\
\text { Serviços domésticos } \\
\text { Comércio } \\
\text { Indústria }\end{array}$ \\
\hline
\end{tabular}

Fonte: Berdegué et alii (2000) e Laurenti e Del Grossi (2000).

Nota: Foram realizadas algumas pequenas mudanças nas tipologias propostas por Berdegué et alii (2000) e Laurenti e Del Grossi (2000).

Os motores do crescimento das atividades não-agrícolas de uma localidade rural são endógenos (rural) ou exógenos (urbano). No primeiro caso, eles podem estar vinculados à modernização da agricultura e ao consumo final da própria população rural. O dinamismo da produção agrícola é um determinante importante do nível de emprego RNA, pois ele influencia o grau de integração da agricultura com a indústria a montante e a jusante, estimulando a demanda por insumos e serviços destinados à lavoura e o desenvolvimento da agroindústria local (ver linha I do Quadro 1). O resultado é que as localidades pobres em recursos e com agricultura atrasada, embora precisem mais das atividades RNA, teriam menor possibilidade de desenvolvê-las.

O mesmo acontece em relação ao consumo final da população rural. As localidades rurais com nível de renda elevado tendem a ter uma maior demanda por produtos não alimentares como proporção do gasto total, bem como a diversificar sua dieta, consumindo mais alimentos processados (ver linha II). É importante ressaltar, porém, que essa dinâmica associada à demanda final também depende do contingente populacional e da concentração da renda. Localidades onde o produto interno é quase exclusivamente agrícola e existe um pequeno número de agricultores com renda per capita elevada, por exemplo, podem não dispor de um mercado 
consumidor suficiente para a diversificação da economia. ${ }^{2}$ Regiões pouco povoadas, por sua vez, costumam sofrer com a carência de serviços públicos que também geram empregos (ver linha III).

Os motores exógenos do desenvolvimento das atividades RNA estão situados em áreas urbanas e resultam, em boa medida, da influência que as médias e grandes cidades exercem sobre seu entorno rural. As cidades demandam um conjunto de bens e serviços que só podem ser produzidos no meio rural, como turismo de praia e de campo, artesanatos locais, construção de hotéis, pousadas e casas para repouso e lazer nas férias e fins de semana, e serviços domésticos para quem dispõe deste tipo de residência temporária (ver linha IV). Além disso, elas oferecem um mercado de trabalho tanto para as pessoas que já vivem no meio rural e estão dispostas a se deslocar para trabalhar nas cidades, quanto para parte da população urbana que mantém o seu local de trabalho, mas transfere sua residência fixa para o meio rural, buscando melhor qualidade de vida ou moradia mais barata (ver linha V).

Outros motores exógenos encontrados em algumas localidades rurais de países da América Latina são os investimentos em turismo, mineração e manufatura (ver BERDEGUÉ et alii, 2000). Um exemplo claro é Cancun, uma região de belas praias onde "a promoção planejada do Estado de investimentos no turismo transformou rapidamente uma área rural adormecida em uma região com modernas atividades rurais não-agrícolas.” (ver REARDON, 2001, p. 398). As localidades rurais pobres freqüentemente estão distantes de importantes centros urbanos e sofrem com a dificuldade de acesso à demanda externa por bens e serviços que elas podem produzir e a um mercado de trabalho com maior oferta de empregos. Quando isso acontece, os investimentos vindos de outras áreas também tendem a ser baixos.

Em suma, pode se observar que as famílias rurais relativamente pobres têm grande necessidade de diversificar a renda por meio de ocupações não-agrícolas, mas sua capacidade é bastante limitada em termos das condições necessárias para participar das atividades: capital inicial, garantias para a obtenção de crédito, educação, acesso a mercado consumidor amplo e infra-estrutura. As políticas de desenvolvimento rural devem assim considerar esse problema e buscar ações favoráveis a uma maior participação da população de baixa renda e das famílias de pequenos agricultores no processo de expansão das atividades não-agrícolas.

2 Para Laurenti e Del Grossi (2000, p. 63), por exemplo, o crescimento das atividades RNA associado ao consumo final dos agricultores é provavelmente mais importante nas localidades de maior concentração de unidades agrícolas de pequena escala de produção. 


\section{INFORMAÇÕES SOBRE A BASE DE DADOS}

Neste estudo, utilizaremos os dados individuais (microdados) da pesquisa amostral do Censo Demográfico $2000^{3}$ para as pessoas residentes em domicílios particulares permanentes. Como o nosso objeto principal de estudo é a população rural, optamos por excluir da amostra todos os indivíduos que moravam em domicílio particular improvisado ou coletivo. A localização da moradia de uma parte significativa desse grupo pode ser apenas casual e temporária, como parece ser o caso de quem vive em hotéis, presídios, quartéis, hospitais, orfanatos, trailers e barracas.

Uma questão metodológica relevante, ao se pesquisar o nível de desigualdade na distribuição da renda de uma população qualquer, é a escolha da variável de análise. Para analisar a condição de vida das pessoas que vivem no meio rural, entende-se que a variável a ser estudada deve ser a renda domiciliar per capita. O rendimento mensal domiciliar é a "soma dos valores dos rendimentos nominais mensais, dos moradores do domicílio, expressa em reais $(R \$)$, exclusive das pessoas consideradas na condição do domicílio como pensionistas, empregados domésticos e parentes dos empregados domésticos" (IBGE, 2002, p. 88). Todos estes últimos indivíduos foram então excluídos da nossa amostra e o valor do rendimento domiciliar per capita foi obtido dividindo-se o valor do rendimento mensal domiciliar pelo número de moradores do domicílio classificados como pessoa de referência, cônjuge, filhos, outros parentes e agregados.

São encontradas, na literatura, críticas à forma de delimitação das áreas oficialmente rurais e urbanas do Brasil, a qual diverge da prevalecente na grande maioria dos países e em todos aqueles de importância econômica igual ou superior à nossa. Na maioria dos países, os critérios utilizados para a demarcação são o número de habitantes da localidade, sua densidade populacional, ou a combinação das duas variáveis. No Brasil, ao contrário, se usa o critério da delimitação administrativa, que classifica como área urbana toda sede de município e de distrito, independente de seu tamanho e características socioeconômicas (VEIGA, 2003). Todo o resto compõe as áreas rurais.

O resultado é que sedes e distritos de qualquer um dos 3.771 municípios com população urbana inferior a 10 mil pessoas, por exemplo, são consideradas zona urbana nos dados do IBGE, com estatuto legal de cidade igual ao atribuído às grandes cidades como São Paulo, Rio de Janeiro e Salvador (NEY, 2006). Se fosse adotado o limite de 20 mil habitantes, parâmetro freqüente em organizações internacionais, seria rural toda a população urbana dos $4.591 \mathrm{mu}$ nicípios que estão abaixo desse patamar populacional. Para Veiga (2003) e Abramovay (2003), o surgimento de cidades de tamanho irrisório gera a idéia equivocada de que o nível de urbanização no Brasil teria atingido aproximadamente $81 \%$ da população no ano 2000.

3 Na coleta das informações do censo, o IBGE utilizou dois modelos de questionário. O primeiro foi o questionário básico, contendo perguntas referentes às características investigadas para toda população. O segundo questionário foi aplicado apenas nos domicílios selecionados para a realização de uma pesquisa amostral, na qual, além das variáveis investigadas no questionário básico, procurou-se obter outras informações sobre características dos domicílios e de seus moradores referentes a temas como escolaridade, trabalho e rendimento, fundamentais para nosso estudo. 
Preferimos então adotar uma forma de delimitação do espaço rural-urbano diferente da oficial, em que combinaremos três critérios de demarcação: delimitação administrativa, contingente populacional e densidade demográfica. Primeiro classificar-se-á como população rural todas as pessoas cuja situação do domicílio está fora das áreas oficialmente definidas como urbanas no País, independente do tamanho da cidade que circunscreve. Ou seja, todas as áreas rurais no censo também serão aqui denominadas rurais. Nelas residem cerca de 31,4 milhões de pessoas.

Entretanto, também vamos considerar rural parte da população oficialmente definida como urbana. Nos casos em que a população urbana do município é inferior a 20 mil habitantes, ela será considerada rural, exceto se a densidade populacional do município ultrapassar o limite de $60 \mathrm{hab} / \mathrm{km}^{2}$. O espaço rural incluirá, portanto, parte das chamadas “cidades” no País, abrindo a possibilidade de se estudar algo que, entre nós, é uma contradição nos termos: as “cidades rurais” (ABRAMOVAY, 2003). O critério da densidade foi examinado porque uma característica fundamental das áreas rurais é a rarefação populacional e existem municípios com poucos habitantes e alta densidade demográfica. O limite de $60 \mathrm{hab} / \mathrm{km}^{2}$ fixado está abaixo do valor encontrado no estrato de municípios com população oficial urbana de 100.000 a 149.999 habitantes $\left(72,0 \mathrm{hab} / \mathrm{km}^{2}\right)$, que já indicaria um razoável grau de urbanização.

Para o cálculo da densidade populacional nos 5.507 municípios existentes por ocasião do Censo Demográfico de 2000, foi necessário obter a área de cada município. Para 5.435 municípios foi utilizada a área do quadro territorial vigente em 01 de janeiro de 2001, homologado no Diário Oficial da União de 11 de outubro de 2002. Para os demais 72 municípios foram usadas as áreas publicadas na Sinopse Preliminar do Censo 2000, porque suas dimensões foram reduzidas para a instalação de 53 novos municípios em 2001. Entre esses municípios instalados, vale ressaltar, 52 tinham menos de 20 mil habitantes, 48 menos de 10 mil e 47 menos de 5 mil residentes. Pelo critério da delimitação administrativa, a população das sedes municipais e distritais criadas pelas novas prefeituras será classificada, no próximo censo, como urbana, independente de seu contingente populacional.

Pela Tabela 1 pode ser observada a evolução da amostra da população rural e urbana, em que o meio urbano é classificado em três tipos de cidades: a) cidades pequenas, nos casos em que a população oficialmente urbana do município não é considerada rural e tem no máximo 99.999 habitantes; ${ }^{4}$ b) cidade média, quando a população urbana do município é de 100.000 a 299.999 pessoas, e c) cidade grande, para população urbana a partir de 300.000 pessoas. Considerando apenas quem mora em domicílios particulares permanentes e cuja condição no domicílio é de pessoa de referência, cônjuge, filhos, outros parentes e agregados, a metodologia empregada aumentou a população rural do País para cerca de 52,6 milhões de pessoas e reduziu o grau de urbanização para $68,7 \%$.

Uma crítica comum ao tipo de demarcação do espaço rural oficial refere-se a sua "natureza residual”. Como o acesso a serviços básicos e um mínimo de adensamento são suficientes para

4 Como vimos antes, toda a população oficialmente urbana dos municípios inferior a 20 mil habitantes foi considerada rural, exceto quando a densidade populacional do município está acima do limite de 60 hab $/ \mathrm{km}^{2}$. 
que uma localidade qualquer se torne legalmente urbana, o meio rural no País acaba, por definição, condenado ao desaparecimento e assimilado automaticamente à idéia de atraso, carência de serviços e falta de cidadania (ABRAMOVAY, 2003; VEIGA, 2003). Apesar da legitimidade das críticas, a demarcação oficial nos possibilita a classificação de áreas rurais de municípios que abrangem importantes centros urbanos, e a baixa densidade populacional, nessas áreas, é, muitas vezes, a causa fundamental da não disponibilidade de serviços básicos, como educação, saúde e saneamento (GRAZIANO DA SILVA et alii, 2001). ${ }^{5}$

Tabela 1 - Evolução da população após o uso cumulativo das restrições ${ }^{1}$. Brasil, 2000

\begin{tabular}{|c|c|c|c|c|c|}
\hline \multirow{2}{*}{ Estatísticas } & \multicolumn{2}{|c|}{ População rural } & \multicolumn{3}{|c|}{ População urbana de cidades } \\
\hline & Oficial & Cidades & Pequenas & Médias & Grandes \\
\hline \multirow[t]{2}{*}{ População total } & 31.947 .618 & 21.417 .441 & 35.148 .218 & 24.043 .559 & 57.316 .019 \\
\hline & {$[4.872 .096]$} & [3.407.101] & [3.769.884] & [2.432.431] & {$[5.792 .900]$} \\
\hline Exclusive domicílios & 31.471 .905 & 21.234 .680 & 34.907 .824 & 23.902 .644 & 56.933 .440 \\
\hline improvisados e coletivos & {$[4.801 .335]$} & {$[3.377 .537]$} & [3.744.048] & [2.418.200] & {$[5.754 .507]$} \\
\hline Exclusive pensionistas e & 31.434 .287 & 21.181 .770 & 34.810 .512 & 23.830 .789 & 56.581 .218 \\
\hline empregados domésticos & {$[4.795 .726]$} & [3.369.627] & [3.733.841] & {$[2.410 .923]$} & {$[5.719 .416]$} \\
\hline Exclusive domicilios com & 28.622 .616 & 20.328 .020 & 33.649 .807 & 23.049 .472 & 54.742 .323 \\
\hline rendimento igual a zero & {$[4.372 .604]$} & {$[3.236 .226]$} & [3.606.884] & {$[2.331 .583]$} & {$[5.532 .267]$} \\
\hline Exclusive domicílios com renda & 28.621 .958 & 20.327 .205 & 33.647 .917 & 23.048 .023 & 54.735 .603 \\
\hline domiciliar per capita $>30.000$ & {$[4.372 .518]$} & [3.236.106] & [3.606.685] & [2.331.429] & [5.531.585] \\
\hline
\end{tabular}

Fonte: Elaboração dos autores.

Nota: ${ }^{1}$ Os valores entre colchetes se referem ao tamanho da amostra. Os demais representam a estimativa da população, obtida por meio do fator de expansão.

Além dos problemas de natureza metodológica, o censo apresenta dados estranhos na cauda inferior e superior da distribuição da renda. Por um lado, existe um número significativo de domicílios em que o valor do rendimento total declarado é nulo. Ele não representaria grave problema se estivesse restrito às famílias com todos os membros desocupados ou, se tivesse alguém ocupado, fosse em atividade muito mal remunerada. Em boa parte dos casos, porém, no domicílio vive pelo menos um membro empregado como militar do exército, delegado, juiz, médico, entre outras profissões cuja renda é alta. Por outro lado, há pessoas ocupadas em atividades de baixa remuneração, como de higiene, garçom, marceneiro e vigia, que informaram renda muito elevada, algumas até mesmo acima de $\mathrm{R} \$ 100.000$ por mês, colocando novamente em dúvida se o valor do rendimento declarado corresponde de fato ao recebido.

5 Graziano da Silva et alii (2001) analisam algumas críticas feitas por Veiga ao critério de demarcação do espaço rural oficial. 
A fim de contornar os dois problemas e obter um conjunto de informações mais coerentes e homogêneas sobre as características da distribuição da renda, excluímos da amostra as pessoas com renda domiciliar per capita igual a zero e as com valor maior do que $\mathrm{R} \$ 30.000$. Conforme pode se observar na Tabela 1, depois da aplicação das restrições referentes à renda domiciliar, a população residente no meio rural oficial, nas cidades rurais, cidades pequenas, cidades médias e cidades grandes, foi reduzida, respectivamente, de 31.434 .287 para 28.621.958 (-8,9\%), de 21.181.770 para 20.327.205 $(-4,0 \%)$, de 34.810 .512 para $33.647 .917(-3,3 \%)$, de 23.830 .789 para $23.048 .023(-3,3 \%)$ e de 56.581 .218 para $54.735 .603(-3,3 \%)$.

\section{PARTICIPAÇÃo DA RENDA NÃO-AGRÍCOLA NO RENDIMENTO DAS FAMÍlIAS RU- RAIS}

No censo demográfico, não há informações sobre o tipo de atividade secundária de quem tinha mais de um trabalho na semana de referência da pesquisa. Nossas análises serão assim desenvolvidas tendo como única referência a atividade principal das pessoas ocupadas. De qualquer forma, vale ressaltar que uma fração muito pequena, de menos de $3 \%$ da população economicamente ativa (PEA) ocupada, no meio rural, informou ter dupla atividade (ver Tabela 2).

Os dados da Tabela 2 mostram que o meio rural não deve ser caracterizado como um espaço quase exclusivamente agrícola, embora sua população esteja majoritariamente ocupada na atividade: são 10,2 milhões de pessoas com trabalho principal no setor primário e 9,3 milhões de ocupados nos setores secundário e terciário. Outra característica importante é a diferença existente entre a composição setorial da mão-de-obra nas áreas rurais oficiais e nas cidades rurais, onde a proporção de pessoas com trabalho principal em atividades não-agrícolas, no âmbito da PEA ocupada, é de, respectivamente, 28,1\% e 76,5\%. Nesse sentido, o uso exclusivo do critério da delimitação administrativa nos estudos sobre o meio rural brasileiro, algo muito freqüente na literatura, pode estar subestimando a importância das atividades não-agrícolas na geração de emprego e renda em áreas de baixo contingente populacional do País.

Se, por um lado, o meio rural é uma categoria espacial cuja delimitação claramente não deve depender da exclusividade ou até mesmo da predominância da atividade agrícola, por outro, ele é o local de residência de mais de 85,5\% dos agricultores. Do total de 12 milhões de brasileiros ocupados com atividade principal na agricultura, 8,5 milhões $(71,0 \%)$ moravam no meio rural oficial, 1,7 milhão (14,6\%), nas cidades rurais, 1,3 milhão (10,5\%), nas cidades urbanas pequenas, 274 mil (2,3\%), nas cidades médias, e apenas 204 mil (1,7\%), nas cidades grandes. Conforme se pode observar, uma proporção diminuta de agricultores vive em cidades com população superior a 100 mil habitantes. 
Tabela 2 - Pessoas com 10 anos ou mais de idade residentes em domicílios particulares permanentes no meio rural e urbano, conforme condição de ocupação, número de trabalhos e ramo de atividade principal ${ }^{1}$. Brasil, 2000

\begin{tabular}{|c|c|c|c|c|c|}
\hline \multirow{2}{*}{ Estatísticas } & \multicolumn{2}{|c|}{ População rural } & \multicolumn{3}{|c|}{ População urbana de cidades } \\
\hline & Oficial & Cidades & Pequenas & Médias & Grandes \\
\hline População com idade $\geq 10$ anos & 24.128 .127 & 16.894 .871 & 28.076 .630 & 19.265 .532 & 46.803 .920 \\
\hline Economicamente ativos & 12.853 .088 & 9.069 .664 & 15.781 .215 & 11.181.274 & 27.469 .373 \\
\hline Ocupados & 11.947 .913 & 7.805 .116 & 13.226 .761 & 9.190 .896 & 22.436 .611 \\
\hline Agrícolas & 8.497 .260 & 1.741 .868 & 1.252 .629 & 274.369 & 204.468 \\
\hline Com um trabalho & 8.311 .165 & 1.712 .782 & 1.231 .720 & 268.831 & 199.771 \\
\hline Com mais de um trabalho & 186.095 & 29.086 & 20.909 & 5.538 & 4.698 \\
\hline Não-agrícolas & 3.360 .445 & 5.973 .670 & 11.808 .329 & 8.782 .510 & 21.886 .575 \\
\hline Com um trabalho & 3.250 .895 & 5.730 .361 & 11.375 .446 & 8.472 .605 & 20.987 .252 \\
\hline Com mais de um trabalho & 109.550 & 243.309 & 432.883 & 309.905 & 899.323 \\
\hline Mal especificada & 90.208 & 89.577 & 165.804 & 134.017 & 345.567 \\
\hline Não-ocupados ${ }^{2}$ & 905.175 & 1.264 .548 & 2.554 .454 & 1.990 .378 & 5.032 .762 \\
\hline Não-economicamente ativos & 11.275 .040 & 7.825 .207 & 12.295 .415 & 8.084 .258 & 19.334 .548 \\
\hline
\end{tabular}

Fonte: Elaboração dos autores.

Notas: ${ }^{1}$ Como a tabela se destina a mostrar o número de pessoas ocupadas, sem considerar o valor de sua renda no trabalho principal, não foram excluídas as pessoas com 10 anos ou mais de idade que moravam em domicílios com renda per capita igual a zero e maior do que $\mathrm{R} \$ 30.000 .^{2}$ A categoria se refere às pessoas não ocupadas que, no período de 30 de junho a 29 de julho de 2000, tomaram providência para conseguir algum trabalho.

A participação das ocupações não-agrícolas no trabalho e, sobretudo, na renda rural se torna ainda maior quando são analisadas exclusivamente as pessoas com informação de valor positivo para o rendimento na atividade principal. Primeiro porque o contingente de pessoas ocupadas sem remuneração na agricultura é de cerca de 3,7 milhões, valor muito maior do que os 273 mil trabalhadores não remunerados nos demais setores de atividade. Em todo o meio rural, o número de pessoas ocupadas com remuneração é de 6,5 milhões no setor primário e 9,1 milhões nos setores secundário e terciário. O segundo motivo é que, no âmbito da PEA rural ocupada com rendimento no trabalho principal, a renda média de quem trabalha em atividades não-agrícolas de $\mathrm{R} \$ 399,5$ é substancialmente maior do que a média de $\mathrm{R} \$ 280,6$ na agricultura (ver Tabela 3).

De acordo com os dados da Tabela 3, a participação das atividades não-agrícolas na renda total do trabalho principal é de 65,7\% no meio rural como um todo, 44,0\% no rural oficial e de $84,2 \%$ nas cidades rurais. Nota-se que, em qualquer uma das áreas aqui classificadas como de 
baixo contingente populacional no País, as atividades industriais e de serviços já representam uma parcela da renda grande o suficiente para exercer forte influência na desigualdade.

Tabela 3 - Pessoas economicamente ativas ocupadas com rendimento no trabalho principal e valor da renda média e mediana mensal do trabalho principal, conforme tipo de domicílio rural e ramo de atividade. Brasil, 2000

\begin{tabular}{|c|c|c|c|c|c|}
\hline \multirow{2}{*}{ Estatística } & \multicolumn{2}{|c|}{ População ocupada } & \multicolumn{2}{|c|}{ Rendimento } & \multirow{2}{*}{$\begin{array}{c}\% \text { na renda } \\
\text { Total }\end{array}$} \\
\hline & Pessoas & $\%$ no total & Médio & Mediano & \\
\hline Todo rural & 15.756 .206 & 100,0 & 349,6 & 190,0 & 100,0 \\
\hline Agrícola & 6.521 .998 & 41,4 & 280,6 & 151,0 & 33,2 \\
\hline Não-agrícola & 9.061 .351 & 57,5 & 399,5 & 210,0 & 65,7 \\
\hline Mal especificada & 172.857 & 1,1 & 329,5 & 195,0 & 1,0 \\
\hline Rural oficial & 8.460 .231 & 100,0 & 298,7 & 151,0 & 100,0 \\
\hline Agrícola & 5.141 .918 & 60,8 & 270,4 & 151,0 & 55,0 \\
\hline Não-agrícola & 3.232 .886 & 38,2 & 343,9 & 200,0 & 44,0 \\
\hline Mal especificada & 85.427 & 1,0 & 295,8 & 160,0 & 1,0 \\
\hline Cidades rurais & 7.295 .975 & 100,0 & 408,0 & 200,0 & 100,0 \\
\hline Agrícola & 1.380 .080 & 18,9 & 318,7 & 160,0 & 14,8 \\
\hline Não-agrícola & 5.828 .465 & 79,9 & 430,4 & 226,0 & 84,2 \\
\hline Mal especificada & 87.430 & 1,2 & 362,5 & 200,0 & 1,1 \\
\hline
\end{tabular}

Fonte: Elaboração dos autores.

Além dos rendimentos do trabalho, deve-se ainda destacar a presença de outros cinco componentes da renda das famílias rurais discriminados pelo IBGE: a) aposentadoria ou pensão; b) aluguel; c) pensão alimentícia, mesada ou doação; d) renda mínima, bolsa-escola ou seguro-desemprego, e e) outros rendimentos (IBGE, 2002). Somados representam, tanto nas áreas oficialmente rurais do País quanto nas cidades rurais, aproximadamente $22 \%$ da renda total (ver Tabela 4). Embora eles também sejam fontes de renda não-agrícolas importantes para a população rural, o foco de nossas análises estará nas atividades RNA, ou seja, no conjunto de atividades industriais e de serviços, nosso objeto principal de estudo. Para simplificar, apenas as rendas provenientes dessas atividades serão chamadas de renda RNA.

O trabalho principal responde por quase $76 \%$ do rendimento domiciliar rural, sendo as atividades não-agrícolas responsáveis por $49,7 \%$ da renda total, no meio rural como um todo, $33,2 \%$, nas áreas oficialmente rurais, e 63,9\%, nas cidades rurais. A participação do setor primário, por sua vez, é de 25,1\%, 41,5\% e 11,2\%, respectivamente. Apenas cerca de 3\% da renda total, em cada uma das duas áreas rurais delimitadas na pesquisa, provém de atividades não definidas no censo, ou seja, de atividades "mal especificadas" e dos trabalhos secundários (demais trabalhos). 
Tabela 4 - Participação das fontes do rendimento das pessoas residentes em domicílios particulares permanentes, conforme situação de domicílio. Brasil, 2000

\begin{tabular}{|c|c|c|c|c|c|c|c|c|}
\hline \multirow{2}{*}{ Estatística } & \multirow{2}{*}{ Brasil } & \multicolumn{3}{|c|}{ População rural } & \multicolumn{4}{|c|}{ População urbana de cidades } \\
\hline & & Total & Oficial & Cidades & Total & Pequenas & Médias & Grandes \\
\hline Trabalho principal & 75,3 & 75,7 & 75,4 & 75,9 & 75,2 & 75,8 & 77,1 & 74,5 \\
\hline Agrícola & 5,2 & 25,1 & 41,5 & 11,2 & 1,7 & 5,0 & 2,0 & 0,6 \\
\hline Não-agrícola & 69,0 & 49,7 & 33,2 & 63,9 & 72,4 & 69,9 & 74,1 & 72,7 \\
\hline Mal especificada & 1,1 & 0,8 & 0,8 & 0,8 & 1,1 & 0,9 & 1,1 & 1,2 \\
\hline Demais trabalhos & 2,5 & 2,2 & 1,7 & 2,7 & 2,6 & 2,4 & 2,4 & 2,6 \\
\hline Aposent. e pensões & 16,1 & 16,9 & 17,8 & 16,1 & 16,0 & 15,9 & 14,5 & 16,4 \\
\hline Aluguéis & 2,8 & 1,8 & 1,5 & 2,1 & 3,0 & 2,8 & 2,9 & 3,2 \\
\hline Pensão alimentícia & 1,3 & 0,8 & 0,6 & 0,9 & 1,4 & 1,2 & 1,3 & 1,5 \\
\hline Renda mínima & 0,3 & 0,4 & 0,5 & 0,3 & 0,3 & 0,4 & 0,4 & 0,3 \\
\hline Outros rendimentos & 1,7 & 2,2 & 2,6 & 1,9 & 1,6 & 1,6 & 1,5 & 1,6 \\
\hline Total & 100,0 & 100,0 & 100,0 & 100,0 & 100,0 & 100,0 & 100,0 & 100,0 \\
\hline
\end{tabular}

Fonte: Elaboração dos autores.

A fim de analisar a relação existente entre a participação da renda das atividades nãoagrícolas no rendimento total dos domicílios rurais e o nível de renda domiciliar, dividimos a população rural em cinco estratos de rendimento, delimitados pelos valores dos quintis da distribuição da renda domiciliar per capita (ver Tabela 5). O primeiro estrato abrange as pessoas com rendimento inferior ao valor do primeiro quintil: $\mathrm{R} \$ 32,5$, em todo meio rural, $\mathrm{R} \$ 26,7$, no rural oficial, e $\mathrm{R} \$ 45,2$, nas cidades rurais. Em cada uma dessas três áreas rurais, o segundo, terceiro, quarto e quinto estratos são compostos, respectivamente, por quem tem renda maior ou igual ao primeiro quintil e inferior ao segundo quintil, maior ou igual ao segundo quintil e inferior ao terceiro quintil, maior ou igual ao terceiro quintil e inferior ao quarto quintil, e maior ou igual ao quarto quintil.

Tabela 5 - Valor em $\mathbf{R} \$$ dos quintis da distribuição da renda domiciliar per capita. Regiões rurais, 2000

\begin{tabular}{lccc}
\hline Estatística & Todo do rural & Rural oficial & Cidades rurais \\
\hline $1^{0}$ quintil & 32,5 & 26,7 & 45,2 \\
$2^{0}$ quintil & 60,0 & 50,0 & 79,0 \\
$3^{0}$ quintil & 100,0 & 80,0 & 133,3 \\
$4^{\circ}$ quintil & 175,5 & 150,0 & 230,0 \\
\hline
\end{tabular}

Fonte: Elaboração dos autores. 
De acordo com os dados da Tabela 6, a participação da renda das ocupações não-agrícolas no rendimento dos domicílios rurais tende a ser tão maior quanto mais alto é o nível da renda domiciliar. Sua participação sobe sistematicamente de $26,6 \%$ da renda total no estrato dos $20 \%$ mais pobres ( $1^{\circ}$ quinto) da população até chegar aos $55,8 \%$ no estrato dos $20 \%$ mais ricos ( $5^{\circ}$ quinto). A participação das atividades agrícolas, ao contrário, diminui com o aumento da renda domiciliar e é muito maior entre os mais pobres do que entre os mais ricos. Enquanto elas representam quase a metade $(48,5 \%)$ de toda a renda obtida pelo $1^{\circ}$ quinto e quase $40 \%$ $(38,8 \%)$ da apropriada pelo $2^{\circ}$ quinto da população, a proporção no $4^{\circ}$ quinto é de pouco mais de $1 / 4(25,6 \%)$ e no $5^{\circ}$ quinto de $21,7 \%$. Nota-se ainda que no $3^{-0}$ quinto a parcela da renda RNA $(39,2 \%)$ ultrapassa a agrícola $(32,1 \%)$.

Tabela 6 - Participação dos componentes da renda das famílias rurais, conforme estratos de renda domiciliar per capita delimitados pelos quintis. Regiões rurais, 2000

\begin{tabular}{|c|c|c|c|c|c|c|c|c|c|}
\hline \multirow{2}{*}{\multicolumn{2}{|c|}{ Estrato }} & \multicolumn{3}{|c|}{ Atividades } & \multirow{3}{*}{$\begin{array}{c}\text { Aposent. e } \\
\text { pensões }\end{array}$} & \multirow{3}{*}{$\begin{array}{c}\text { Aluguéis } \\
0,5\end{array}$} & \multirow{3}{*}{$\begin{array}{c}\text { Doações }^{2} \\
1,4\end{array}$} & \multirow{3}{*}{$\begin{array}{c}\begin{array}{c}\text { Renda } \\
\text { mínima }^{3}\end{array} \\
1,7\end{array}$} & \multirow{3}{*}{$\begin{array}{c}\begin{array}{c}\text { Outras } \\
\text { Rendas }\end{array} \\
4,3\end{array}$} \\
\hline & & \multirow{2}{*}{$\begin{array}{c}\text { Agrícola } \\
48,5\end{array}$} & \multirow{2}{*}{$\begin{array}{c}\text { Não-agrícola } \\
26,6\end{array}$} & \multirow{2}{*}{$\begin{array}{c}\text { Indefinidas }^{1} \\
1,1\end{array}$} & & & & & \\
\hline \multirow{5}{*}{ 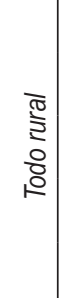 } & $1^{0}$ quinto & & & & & & & & \\
\hline & $2^{\circ}$ quinto & 38,8 & 33,8 & 1,3 & 21,3 & 0,5 & 1,0 & 1,1 & 2,4 \\
\hline & $3^{0}$ quinto & 32,1 & 39,2 & 1,4 & 23,2 & 0,6 & 0,9 & 0,8 & 1,8 \\
\hline & $4^{0}$ quinto & 25,6 & 43,4 & 1,6 & 25,7 & 0,9 & 0,8 & 0,5 & 1,5 \\
\hline & $5^{0}$ quinto & 21,7 & 55,8 & 3,9 & 12,9 & 2,4 & 0,7 & 0,2 & 2,4 \\
\hline \multirow{5}{*}{ 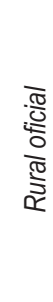 } & $1^{0}$ quinto & 60,0 & 17,6 & 1,0 & 12,6 & 0,4 & 1,1 & 1,9 & 5,4 \\
\hline & $2^{\circ}$ quinto & 50,6 & 23,2 & 1,2 & 19,7 & 0,4 & 0,8 & 1,2 & 2,9 \\
\hline & $3^{0}$ quinto & 44,1 & 25,0 & 1,2 & 25,7 & 0,4 & 0,6 & 0,7 & 2,2 \\
\hline & $4^{0}$ quinto & 41,5 & 32,1 & 1,6 & 20,8 & 0,7 & 0,6 & 0,6 & 2,1 \\
\hline & $5^{\circ}$ quinto & 39,3 & 36,6 & 3,0 & 15,6 & 2,0 & 0,5 & 0,2 & 2,7 \\
\hline \multirow{5}{*}{ 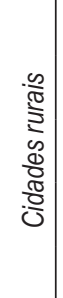 } & $1^{0}$ quinto & 23,1 & 50,3 & 1,4 & 18,5 & 0,7 & 2,0 & 1,4 & 2,6 \\
\hline & $2^{\circ}$ quinto & 17,4 & 51,7 & 1,4 & 25,3 & 0,6 & 1,3 & 0,9 & 1,4 \\
\hline & $3^{0}$ quinto & 15,7 & 60,3 & 1,7 & 18,2 & 1,0 & 1,1 & 0,7 & 1,2 \\
\hline & $4^{0}$ quinto & 11,2 & 60,0 & 2,0 & 22,7 & 1,5 & 1,0 & 0,5 & 1,1 \\
\hline & $5^{\circ}$ quinto & 9,2 & 67,5 & 4,6 & 12,8 & 2,7 & 0,8 & 0,2 & 2,3 \\
\hline
\end{tabular}

Fonte: Elaboração dos autores.

Nota: ${ }^{1}$ As atividades indefinidas abrangem as atividades principais "mal especificadas" no censo e os trabalhos secundários (“demais trabalhos”). ${ }^{2}$ Rendimentos de pensão alimentícia, mesada e doação. ${ }^{3}$ São as rendas de programas oficiais de auxílio: renda mínima, bolsa-escola, seguro-desemprego, etc.

Se considerarmos exclusivamente as áreas oficialmente rurais do País, veremos que em todos os estratos de renda o peso das atividades agrícolas na renda total é maior do que o das não-agrícolas. No entanto, assim como acontece no meio rural como um todo e nas cidades 
rurais, a relação entre a participação das ocupações RNA no rendimento domiciliar e o nível de renda dos domicílios também é positiva. No rural oficial, o setor primário representa 60,0\% e o conjunto de atividades industriais e de serviços $17,6 \%$ da renda total do quinto mais pobre da população. Na medida em que a renda domiciliar aumenta, esses dois porcentuais convergem até chegar a valores bem próximos no quinto mais rico da distribuição de renda: 39,3\% e 36,6\%, respectivamente (ver Tabela 6).

Os resultados até agora analisados têm como foco a participação das ocupações RNA e não a relação existente entre nível de renda não-agrícola e rendimento domiciliar. E elas podem ser diferentes. Reardon (1999, p. 23) destaca que, em muitos países em desenvolvimento, “a variação do nível absoluto de rendimento não-agrícola entre o estrato de menor e maior renda é muito maior do que a variação da participação". Segundo o autor, "há até casos em que a participação da renda não-agrícola é menor para os níveis mais altos de renda, embora ainda esteja associada a um aumento no nível absoluto de renda não-agrícola”. Esses são os casos, por exemplo, do Kenya, México e Etiópia.

A Figura 2 mostra, em cada estrato da distribuição de renda delimitado anteriormente, o rendimento total não-agrícola dividido pelo número de pessoas. Conforme se pode observar, o nível de renda não-agrícola tende a ser tão maior quanto mais alto é o rendimento da família. No estrato mais pobre da população rural ( $1^{\circ}$ quinto), o resultado da soma de toda renda industrial e de serviços dividido pelo total de pessoas no grupo é de apenas R \$ 5,2. Entre os $20 \%$ mais ricos, a média sobe para $\mathrm{R} \$ 259,7$, valor quase 50 vezes maior. Nota-se ainda que o nível do rendimento não-agrícola cresce sucessivamente do estrato mais pobre ao mais rico da população rural, especialmente do penúltimo ao último quinto, em que o aumento da renda per capita obtida na atividade é bem maior, chegando a mais de $350 \%$.

A Figura 3, por sua vez, destaca o nível e a participação da renda das ocupações nãoagrícolas no rendimento dos domicílios de agricultores empregados, por conta própria e empregadores. Nesse caso, a posição na ocupação serve como proxy da posse da terra, porque no censo não há informações sobre a área dos empreendimentos agrícolas. ${ }^{6}$ Como a hipótese básica é que as diferenças de acesso à terra entre as famílias estão fortemente relacionadas à discriminação ocupacional no setor primário, a classificação dos domicílios com mais de um agricultor, em diferentes posições ocupacionais, prioriza sempre a posição que representa maior capital físico: primeiro a de empregador com mais empregados, depois a de empregador com menos empregados, a de conta própria e, por último, de empregado. ${ }^{7}$

6 Segundo Ney e Hoffmann (2004), os empreendimentos agrícolas dos empregadores têm, em média, 230 ha, valor nove vezes superior à média dos conta própria, 26 ha.

7 Nota-se que a família agrícola só será classificada como de empregado nas situações em que ninguém trabalha como conta própria ou empregador no setor primário. Se, por exemplo, o domicílio tem duas pessoas ocupadas com rendimento na agricultura, sendo que uma trabalha como empregado e outra como empregador, a família é considerada empregadora. Nos domicílios em que há empregado e conta própria no setor, a família é classificada como de conta própria. Caso houvesse conta própria e empregador, a família seria de empregador. 
Figura 2 - Nível e participação da renda não-agrícola no rendimento das famílias rurais, conforme estratos (quintos) de rendimento domiciliar per capita delimitados pelos quintis. Regiões rurais, 2000

a) Todo rural

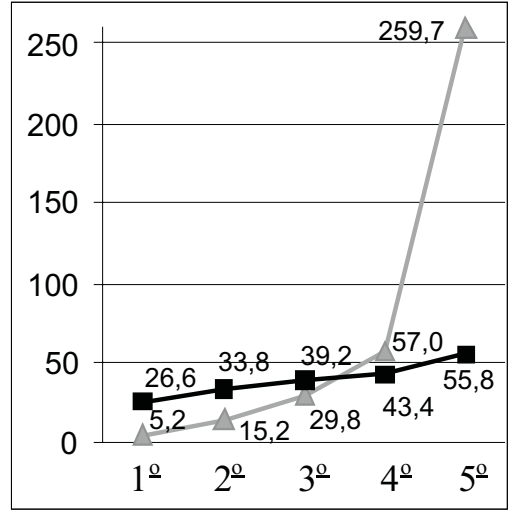

Participação da renda RNA b) Rural oficial

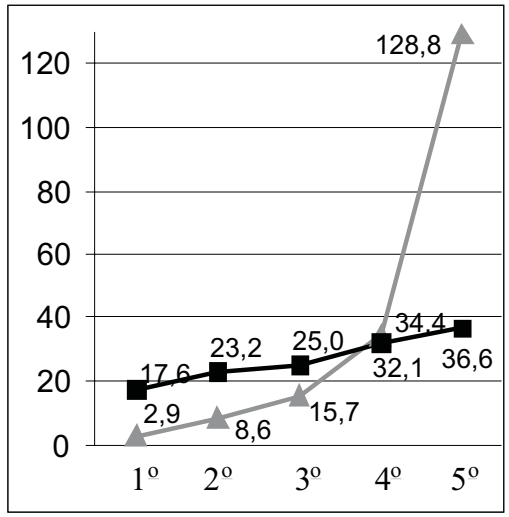

Nível de renda RNA c) Cidades rurais

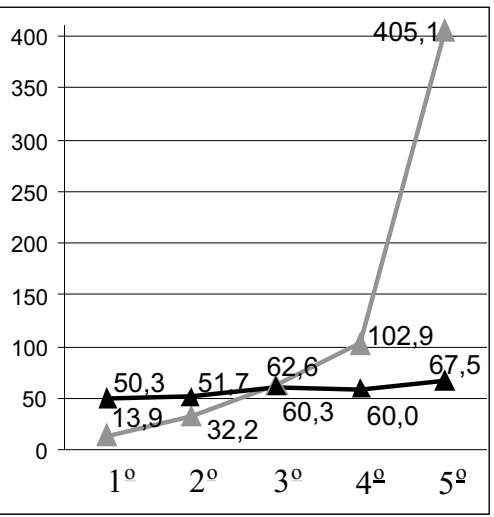

Fonte: Elaboração dos autores.

Figura 3 - Nível e participação da renda não-agrícola no rendimento das famílias rurais, conforme tipos de domicílios agrícolas. Regiões rurais, 2000.

a) Todo rural

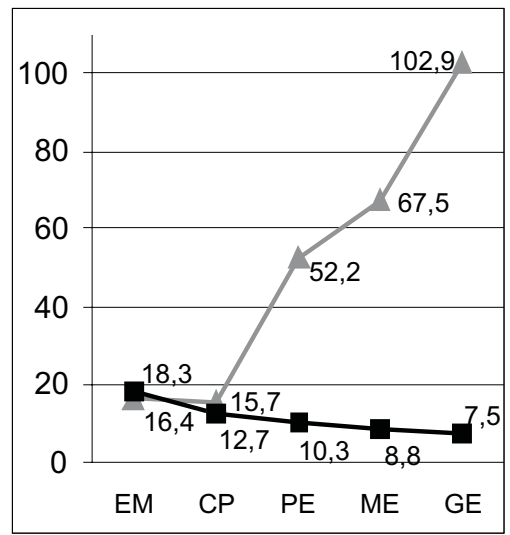

Participação da renda RNA b) Rural oficial

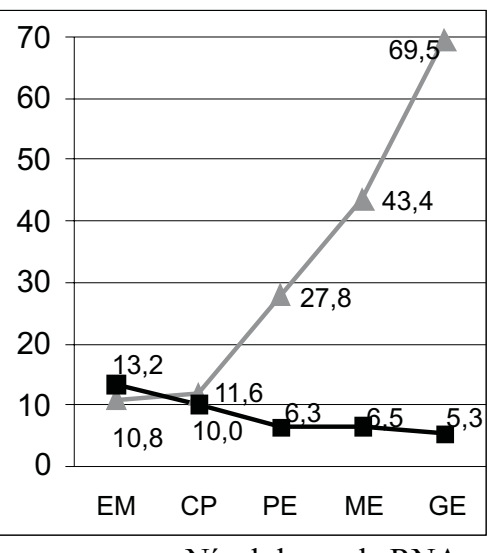

c) Cidades rurais

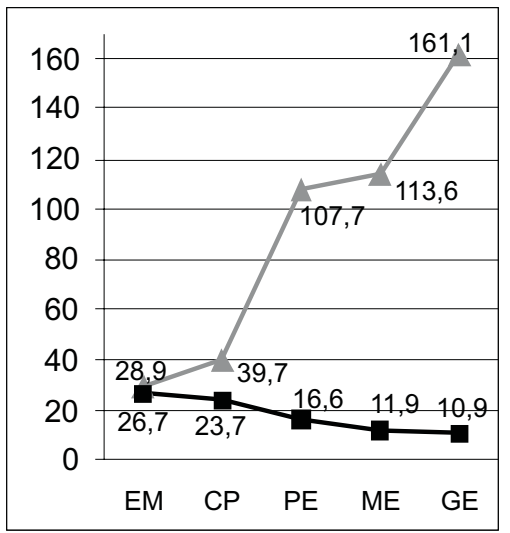

Fonte: Elaboração dos autores.

Notas: As siglas dos tipos de domicílios: EM - Empregado; CP - Conta Própria; PE - Pequeno empregador (com um ou dois empregados); ME - Médio empregador (com 3 a 5 empregados); GE - Grande empregador (com seis ou mais empregados). A posição na ocupação é utilizada como proxy da posse da terra. A hipótese básica é que as diferenças de acesso à terra das famílias estão fortemente correlacionadas com a discriminação ocupacional de empregado, conta própria e empregador no setor primário.

Ao contrário do que acontece com o rendimento das famílias rurais, a participação das atividades secundárias e terciárias na renda dos domicílios agrícolas diminui com o aumento 
da posse da terra, medida pela posição na ocupação das pessoas ocupadas no setor primário. A participação cai de 18,3\%, nos domicílios dos agricultores empregados, para 12,7\%, nos dos conta próprias, 10,3\%, nos dos pequenos empregadores, 8,8\%, nos dos médios empregadores, e 7,5\%, nos dos grandes empregadores. Apesar disso, a soma de toda a renda industrial e de serviços dividida pelo número de pessoas residentes em cada tipo de domicílio agrícola indica que existe uma forte relação linear positiva entre o nível de renda não-agrícola e a posse da terra. Os dados assim sugerem que as famílias com mais área para plantar tendem não só a obter níveis de renda bem maiores no setor primário, como também nos outros setores.

\section{DECOMPOSIÇÃo DO ÍNDICE DE GINI}

Outra maneira de analisar a contribuição de um componente da renda da população rural, particularmente o das atividades agrícolas e não-agrícolas, para a desigualdade na distribuição da renda é por meio da decomposição do índice de Gini. A metodologia permite verificar se cada componente da renda contribui para aumentar ou reduzir a concentração dos rendimentos e ainda estimar sua contribuição para a desigualdade total.

Para decompor a desigualdade, seguiremos a mesma metodologia utilizada por Hoffmann (2003), com base em Kakwani (1977) e Pyatt, Chen e Fei (1980). O valor $y_{i}$ representa o rendimento domiciliar per capita de cada pessoa residente no meio rural, exclusive pensionistas, empregados domésticos, parentes de empregados domésticos e indivíduos que moravam em domicílios com renda per capita igual a zero e maior do que $\mathrm{R} \$ 30.000$. Admitindo que os indivíduos foram ordenados de forma que:

$$
y_{1} \leq y_{2} \leq \ldots \leq y_{n}
$$

sendo $n$ o tamanho da população pesquisada, se $\mu$ representa a média dos valores de $y_{i}$, a renda total é $n \mu$.

Em qualquer ponto dessa seqüência ordenada de rendimentos, podemos calcular tanto a proporção acumulada da população, quanto a proporção acumulada da renda até a $i$-ésima pessoa, dada por:

$$
\Phi_{i}=\frac{1}{n \mu} \sum_{j=1}^{i} y_{j}
$$

A Figura 4 mostra, nas áreas oficialmente rurais e nas cidades rurais, como a proporção acumulada da renda aumenta em função da proporção acumulada de pessoas, tendo sido suas respectivas populações previamente ordenadas conforme valores crescentes do rendimento domiciliar per capita. O conjunto de pontos definidos no sistema de eixos cartesianos ortogonais representa assim a "curva de Lorenz" para a distribuição da renda em cada um dos dois tipos de região rural. O segmento $O B$, chamado de "linha da perfeita igualdade", mostra uma situação 
hipotética extrema da curva de Lorenz em que todas as pessoas receberiam a mesma renda e, conseqüentemente, a proporção acumulada da população seria sempre igual à da renda. A poligonal $O C B$, por sua vez, apresenta outro caso extremo em que toda a renda é apropriada por um único indivíduo. A curva ficaria no eixo das abscissas até a penúltima pessoa e saltaria para o ponto $B$ ao incluir a última pessoa (HOFFMANN, 1998).

Figura 4 - Curva de Lorenz da distribuição da renda domiciliar per capita, conforme tipo de domicílio rural. Regiões rurais, 2000

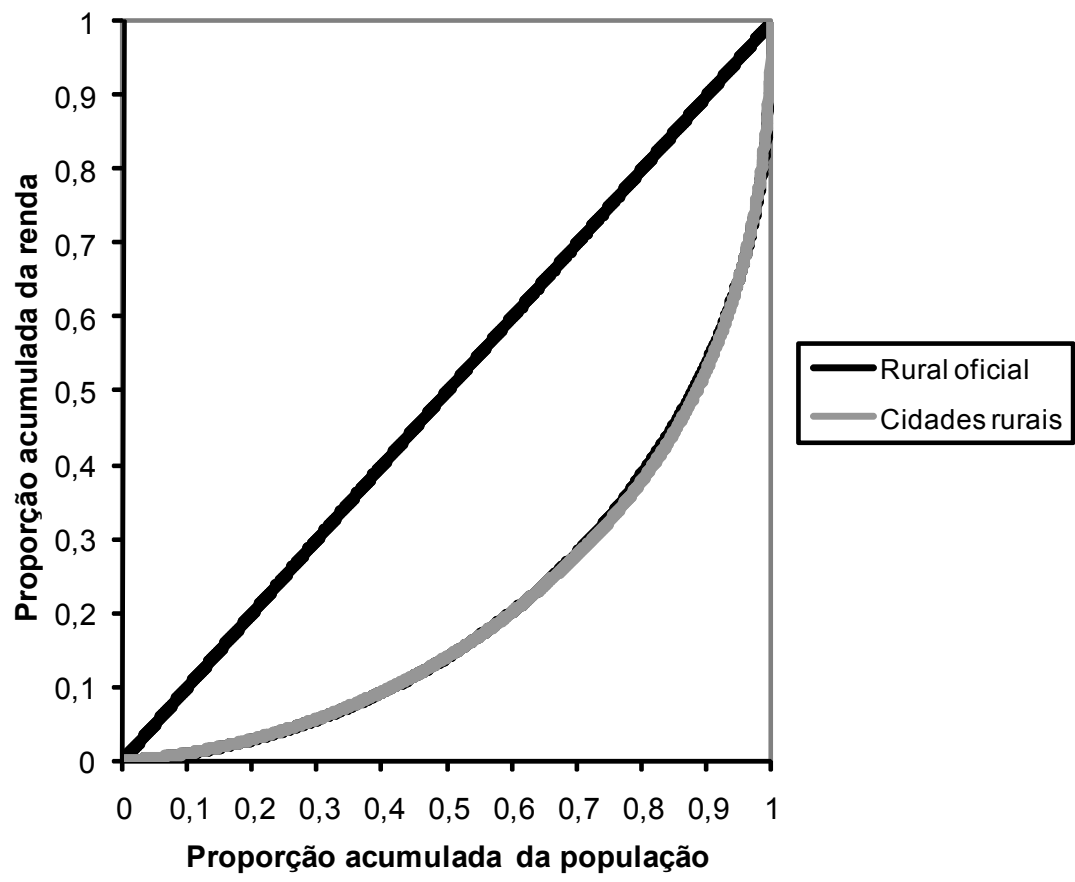

Fonte: Elaboração dos autores.

Em qualquer sociedade, mesmo nas mais igualitárias ou desiguais, a distribuição da renda se dá sempre entre as duas situações extremas de perfeita igualdade e desigualdade, ficando a curva de Lorenz sempre situada dentro do triângulo $O C B$. Quanto mais afastada ela estiver da linha da perfeita igualdade $O B$ e maior for a área cinza $\alpha$, chamada de área de desigualdade, maior será a concentração da renda (ver Figura 4). Nota-se que as curvas de Lorenz da distribuição da renda no meio rural oficial e nas cidades rurais estão praticamente sobrepostas e, por conseguinte, os valores das áreas $\alpha$ e do índice de Gini serão semelhantes.

Por definição, o valor do índice Gini é o dobro do valor da área $\alpha$ :

$$
G=2 \alpha
$$

Sendo $\beta$ a área abaixo da curva de Lorenz e toda a área do triângulo retângulo OCB de base 1 e altura 1 igual a 0,5 , temos: 


$$
\alpha+\beta=0,5
$$

Das equações (3) e (4) temos que:

$$
G=1-2 \beta
$$

Para decompor o índice de Gini, é necessário conhecer as razões de concentração $\left(C_{h}\right)$ dos $k$ componentes (parcelas) da renda domiciliar per capita, bem como sua participação na renda total $\left(\phi_{h}\right)$, já calculada na Tabela 4. Da mesma forma que acontece com o índice de Gini e a curva de Lorenz, a razão de concentração de cada parcela do rendimento é definida a partir da respectiva curva de concentração. Vamos aqui considerar que a renda $\left(y_{i}\right)$ seja a soma de $k$ parcelas:

$$
y_{i}=\sum_{h=1}^{k} y_{h i}
$$

Nesta análise, são consideradas nove parcelas: 1) atividade principal agrícola; 2) atividade principal não-agrícola; 3) atividade mal definida; 4) trabalho secundário (demais trabalhos); 5) aposentadoria ou pensão; 6) aluguel; 7) pensão alimentícia, mesada ou doação; 8) renda mínima, bolsa-escola ou seguro-desemprego, e 9) outros rendimentos.

Mantendo as pessoas dispostas em ordem crescente de valor da renda domiciliar per capita, é possível calcular, para qualquer ponto da seqüência ordenada em (1), a proporção acumulada da h-ésima parcela da renda, dada por:

$$
\Phi_{h i}=\frac{1}{n \mu_{h}} \sum_{j=1}^{i} y_{h j}
$$

sendo $\mu_{h}$ a média dos $n$ valores de $y_{h i}$.

A curva de concentração da parcela $y_{h i}$ mostra como $\Phi_{h i}$ cresce em função da proporção acumulada da população. Na Figura 5, pode se observar a curva de Lorenz da distribuição do rendimento domiciliar per capita e as curvas de concentração de cada componente da renda, no meio rural como um todo. Para analisar a contribuição da renda das ocupações não-agrícolas para a desigualdade, o trabalho principal foi desagregado em agrícola, não-agrícola e de atividades "mal especificadas" no censo demográfico.

A ordenada da curva de Lorenz é uma média ponderada das ordenadas de todas as nove curvas de concentração pela respectiva participação da parcela na renda total $\left(\phi_{h}\right)$. Se uma curva de concentração está sempre abaixo da curva de Lorenz, o componente da renda contribui para aumentar a desigualdade de rendimentos. Esse é o caso da renda dos “demais trabalhos", de aluguéis e, particularmente, das atividades não-agrícolas. No caso das parcelas da renda provenientes de atividades agrícolas, de doações, de aposentadorias ou pensões, e de programas 
oficiais de auxílio, como renda mínima, bolsa-escola e seguro-desemprego, todas as curvas de concentração estão acima da curva de Lorenz. Os quatros componentes, portanto, contribuem para reduzir a desigualdade.

Figura 5 - Curvas de Lorenz e de concentração de cada componente da renda domiciliar per capita. Meio rural, 2000

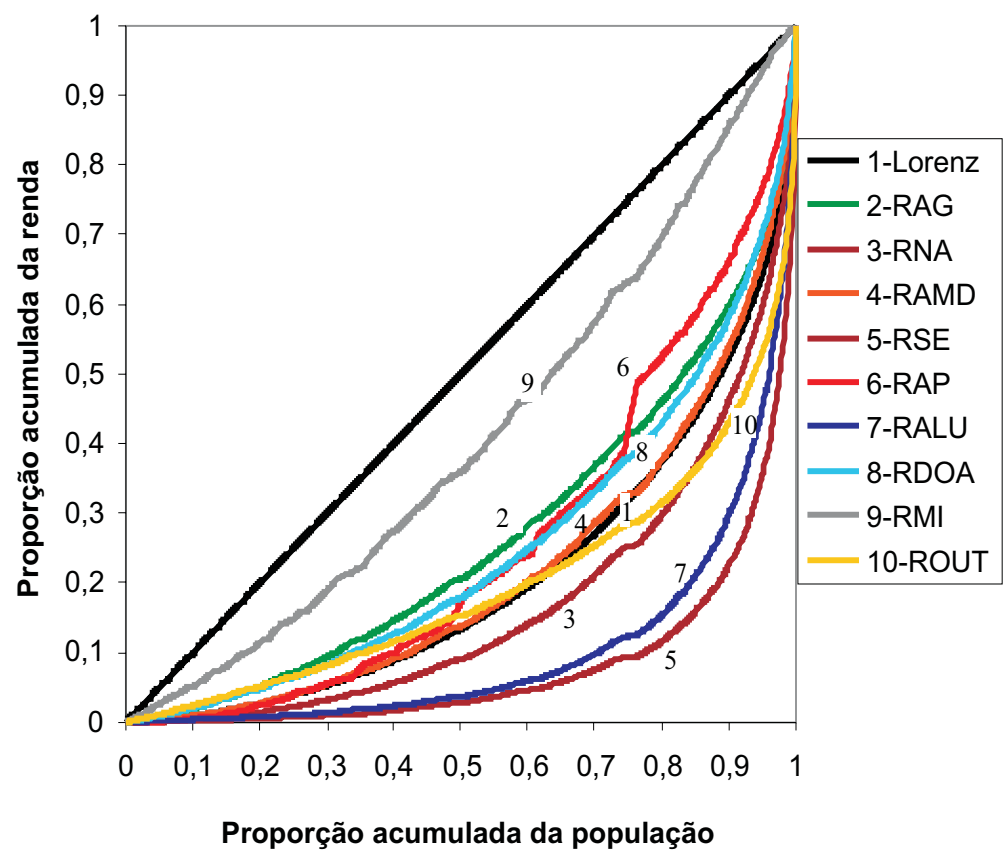

Fonte: Elaboração dos autores.

Nota: As siglas dos componentes da renda significam: Lorenz (1) - Curva de Lorenz, RAG (2) - renda de atividades agrícolas, RNA (3) - renda de atividades não-agrícolas, RAMD (4) - renda de atividades mal definidas, RSE (5) renda de trabalho secundário (demais trabalhos), RAP (6) renda de aposentadoria e pensão, RALU (7) - renda de aluguel, RDOA (8) - renda de pensão alimentícia, mesada ou doação, RMI (9) - renda mínima, bolsa-escola ou seguro-desemprego, ROUT (10) - outros rendimentos.

Definindo por $\beta_{h}$ toda a área compreendida entre a curva de concentração e o eixo das abscissas, a razão de concentração de $y_{\text {li }}$, de forma análoga à expressão (5), pode ser determinada como:

$$
C_{h}=1-2 \beta_{h}
$$

Da mesma maneira que a curva de Lorenz é uma média ponderada das ordenadas das curvas de concentração pela participação das respectivas parcelas na renda total, o índice de Gini de uma distribuição também é uma média ponderada das razões de concentração das nove parcelas da renda domiciliar per capita: 


$$
G=\sum_{h=1}^{k} \phi_{h} C_{h}
$$

Dessa forma, quando a razão de concentração é maior do que o valor do índice de Gini, o componente da renda contribui para aumentar a desigualdade. No caso contrário, quando ela é menor, a parcela contribui para a diminuição das disparidades de rendimentos. Conforme pode-se ainda observar, na equação (9), a contribuição de cada componente para a formação do índice de Gini depende claramente de sua participação na renda total $\left(\phi_{h}\right)$ e da razão de concentração $\left(C_{h}\right)$ :

$$
G=\phi_{1} C_{1}+\phi_{2} C_{2}+\cdots+\phi_{9} C_{9}
$$

A Tabela 7 mostra a razão de concentração $\left(C_{h}\right)$ e a contribuição de cada componente do rendimento para a renda total $\left(\phi_{h}\right)$.

Para a decomposição do índice de Gini em cada região rural, temos:

$G($ todo rural $)=0,589=0,251 \cdot 0,476+0,497 \cdot 0,664+\cdots+0,022 \cdot 0,609=$

$$
=0,120+0,331+\cdots+0,014 ;
$$

$G($ rural oficial $)=0,576=0,415 \cdot 0,536+0,332 \cdot 0,654+\cdots+0,026 \cdot 0,571=$

$$
=0,222+0,216+\cdots+0,015 ;
$$

$G($ cidades rurais $)=0,578=0,112 \cdot 0,448+0,639 \cdot 0,615+\cdots+0,019 \cdot 0,670=$

$$
=0,050+0,393+\cdots+0,013 .
$$

A Tabela 7 mostra também a contribuição de cada componente do rendimento para a desigualdade (\% Gini). Nota-se que o trabalho principal dá origem a 77,2\% das disparidades de renda no meio rural e, como possui uma razão de concentração $(0,601)$ superior ao valor do índice de Gini $(0,589)$, ele contribui para aumentar a desigualdade, o que revela a grande importância de se conhecer a distribuição desse tipo renda e os principais determinantes da sua distribuição. As análises, no entanto, devem considerar as diferenças existentes entre a distribuição da renda agrícola e não-agrícola nos diferentes estratos de renda domiciliar per capita e o efeito de cada atividade na desigualdade rural, objeto principal de nosso estudo.

A razão de concentração da renda no trabalho principal não-agrícola é de 0,664 , no meio rural como um todo, 0,654, nas áreas oficialmente rurais do País, e de 0,615, nas cidades rurais, valores significativamente maiores do que os índices de Gini da distribuição da renda domiciliar per capita de cada região: 0,589, 0,576 e 0,578, respectivamente (ver Tabela 7). Os dados assim indicam que as atividades não-agrícolas, em vez de reduzirem as disparidades de rendimentos nas áreas de baixo contingente populacional do País, contribuem para aumentá- 
las. A afirmação comumente encontrada na literatura e questionada por Reardon et alii (1998a e 1998b) de que a expansão das atividades industriais e de serviços, por si só, deve promover o desenvolvimento eqüitativo do meio rural é incompatível com as informações disponíveis no último censo demográfico.

Tabela 7 - Decomposição do índice de Gini do rendimento domiciliar per capita: razão de concentração $\left(C_{h}\right)$, contribuição do componente para a renda total $\left(\varphi_{h}\right)$ e para o índice de Gini. Regiões rurais, 2000

\begin{tabular}{lccccccccc}
\hline \multirow{2}{*}{ Estatísticas } & \multicolumn{3}{c}{ Todo rural } & \multicolumn{3}{c}{ Rural oficial } & \multicolumn{3}{c}{ Cidades rurais } \\
\cline { 2 - 10 } & \multicolumn{1}{c}{$C_{h}$} & $\varphi_{h}$ & $\%$ Gini & $C_{h}$ & $\varphi_{h}$ & $\%$ Gini & $C_{h}$ & $\varphi_{h}$ & $\%$ Gini \\
\hline Trabalho principal & 0,601 & 0,757 & 77,2 & 0,589 & 0,754 & 77,1 & 0,590 & 0,759 & 77,4 \\
Agrícola & 0,476 & 0,251 & 20,3 & 0,536 & 0,415 & 38,6 & 0,448 & 0,112 & 8,7 \\
Não-agrícola & 0,664 & 0,497 & 56,1 & 0,654 & 0,332 & 37,7 & 0,615 & 0,639 & 68,0 \\
Mal especificada & 0,575 & 0,008 & 0,8 & 0,592 & 0,008 & 0,8 & 0,527 & 0,008 & 0,7 \\
Demais trabalhos & 0,841 & 0,022 & 3,2 & 0,819 & 0,017 & 2,4 & 0,832 & 0,027 & 3,9 \\
Aposent. e pensões & 0,488 & 0,169 & 14,0 & 0,493 & 0,178 & 15,3 & 0,466 & 0,161 & 13,0 \\
Aluguéis & 0,797 & 0,018 & 2,4 & 0,820 & 0,015 & 2,1 & 0,747 & 0,021 & 2,7 \\
Pensão alimentícia & 0,507 & 0,008 & 0,7 & 0,480 & 0,006 & 0,5 & 0,460 & 0,009 & 0,8 \\
Renda mínima & 0,185 & 0,004 & 0,1 & 0,190 & 0,005 & 0,2 & 0,154 & 0,003 & 0,1 \\
Outros rendimentos & 0,609 & 0,022 & 2,3 & 0,571 & 0,026 & 2,6 & 0,670 & 0,019 & 2,2 \\
Total (Índice de Gini) & 0,589 & 1,000 & 100,0 & 0,576 & 1,000 & 100,0 & 0,578 & 1,000 & 100,0 \\
\hline
\end{tabular}

Fonte: Elaboração dos autores.

Conforme se pode observar na Tabela 7, o uso exclusivo do critério da delimitação administrativa na definição do espaço rural oficial, o qual classifica como área urbana sedes de municípios e de distritos com baixo contingente populacional, tende a subestimar não só a população rural do País, como também a participação das ocupações não-agrícolas na sua renda total e na desigualdade de renda. A participação do trabalho não-agrícola no rendimento total e na formação do índice de Gini é a maior entre todos os componentes da renda no meio rural como um todo e nas cidades rurais. No rural oficial, ao contrário, a contribuição da atividade para a desigualdade é inferior à do trabalho agrícola, por causa da maior participação do setor primário na renda.

As atividades agropecuárias, ao contrário, apresentam razão de concentração inferior ao índice de Gini e contribuem para a redução das desigualdades de rendimentos no meio rural. Isso acontece porque uma proporção maior (menor) da renda total do trabalho no setor primário é apropriada pelos domicílios mais pobres (ricos) do que a parcela da renda total gerada nos demais setores de atividades (ver Tabela 8). Em todo o meio rural, por exemplo, 46,0\% da renda 
do setor primário é recebida pelos $80 \%$ mais pobres, ao passo que essa mesma parcela da população fica com menos de $30 \%$ do rendimento das atividades não-agrícolas (ver Tabela 8).

Tabela 8 - Distribuição da renda de cada componente do rendimento em estratos de renda domiciliar per capita. Regiões rurais, 2000

\begin{tabular}{|c|c|c|c|c|c|c|c|c|}
\hline \multirow{2}{*}{ Estatística } & \multicolumn{3}{|c|}{ Atividades } & \multirow{2}{*}{$\begin{array}{c}\text { Aposent. e } \\
\text { Pensões }\end{array}$} & \multirow{2}{*}{ Aluguéis } & \multirow{2}{*}{$\begin{array}{c}\text { Pensão } \\
\text { Alimentícia }\end{array}$} & \multirow{2}{*}{$\begin{array}{l}\text { Renda } \\
\text { Mínima }\end{array}$} & \multirow{2}{*}{$\begin{array}{l}\text { Outras } \\
\text { Rendas }\end{array}$} \\
\hline & Agrícola & Não-agrícola & Indefinidas & & & & & \\
\hline Todo rural & 100,0 & 100,0 & 100,0 & 100,0 & 100,0 & 100,0 & 100,0 & 100,0 \\
\hline $1^{\circ}$ quinto & 5,1 & 1,4 & 1,0 & 2,5 & 0,7 & 4,7 & 11,4 & 5,1 \\
\hline $2^{\circ}$ quinto & 8,9 & 3,9 & 2,4 & 7,3 & 1,5 & 7,5 & 15,6 & 6,1 \\
\hline $3^{\circ}$ quinto & 12,6 & 7,8 & 4,8 & 13,6 & 3,4 & 11,5 & 18,7 & 7,9 \\
\hline $4^{\circ}$ quinto & 19,4 & 16,6 & 10,1 & 28,8 & 9,7 & 19,0 & 23,7 & 12,4 \\
\hline $5^{\circ}$ quinto & 54,0 & 70,3 & 81,7 & 47,8 & 84,8 & 57,2 & 30,6 & 68,6 \\
\hline Rural oficial & 100,0 & 100,0 & 100,0 & 100,0 & 100,0 & 100,0 & 100,0 & 100,0 \\
\hline $1^{\circ}$ quinto & 4,1 & 1,5 & 1,2 & 2,0 & 0,7 & 5,4 & 11,8 & 5,8 \\
\hline $2^{\circ}$ quinto & 7,1 & 4,1 & 2,8 & 6,4 & 1,4 & 7,8 & 15,4 & 6,4 \\
\hline $3^{\circ}$ quinto & 12,0 & 8,5 & 5,6 & 16,2 & 3,2 & 12,6 & 18,1 & 9,3 \\
\hline $4^{\circ}$ quinto & 18,0 & 17,5 & 12,1 & 21,0 & 9,1 & 19,9 & 23,8 & 14,1 \\
\hline $5^{0}$ quinto & 58,8 & 68,5 & 78,3 & 54,3 & 85,5 & 54,2 & 30,9 & 64,3 \\
\hline Cidades rurais & 100,0 & 100,0 & 100,0 & 100,0 & 100,0 & 100,0 & 100,0 & 100,0 \\
\hline $1^{\circ}$ quinto & 5,9 & 2,3 & 1,2 & 3,3 & 1,0 & 5,9 & 11,6 & 3,8 \\
\hline $2^{\circ}$ quinto & 10,0 & 5,2 & 2,5 & 10,1 & 2,0 & 9,1 & 17,0 & 4,9 \\
\hline $3^{\circ}$ quinto & 15,0 & 10,1 & 5,3 & 12,1 & 5,1 & 13,0 & 20,2 & 6,8 \\
\hline $4^{\circ}$ quinto & 17,8 & 16,7 & 10,2 & 25,2 & 12,4 & 18,4 & 24,4 & 10,5 \\
\hline $5^{\circ}$ quinto & 51,3 & 65,7 & 80,8 & 49,3 & 79,6 & 53,5 & 26,8 & 74,0 \\
\hline
\end{tabular}

Fonte: Elaboração dos autores.

Quanto aos outros componentes da renda, a comparação da razão de concentração com o índice de Gini indica que as parcelas referentes aos rendimentos de aluguéis e de trabalhos secundários (demais trabalhos) contribuem para aumentar a desigualdade. Já as parcelas correspondentes aos programas oficiais de auxílio (renda mínima, bolsa-escola ou seguro-desemprego), às aposentadorias ou pensões, às pensões alimentícias, mesadas ou doações, ao contrário, contribuem para reduzir as disparidades de renda.

É importante ressaltar que as atividades não-agrícolas, ao contrário da agrícola, contribuem para aumentar a desigualdade de rendimentos porque sua renda está mais concentrada. O estudo não analisa as causas dessa concentração. Pesquisas realizadas em diversos países em desenvolvimento mostram que algumas condições responsáveis pela desigualdade de renda na agricultura também tendem a afetar, com maior ou menor intensidade, a distribuição da renda RNA. No Brasil, em particular, os principais determinantes estruturais da disparidade de ren- 
da no setor primário, encontrados na literatura, são: a concentração fundiária, a educação e as desigualdades regionais. Entre eles, estudos coincidem em destacar a estrutura fundiária como o principal fator responsável pela enorme concentração da renda agrícola. ${ }^{8}$

Em relação especificamente aos efeitos da educação e da localização dos domicílios rurais na conformação da renda não-agrícola, porém, as evidências encontradas em outros países subdesenvolvidos indicam que eles seriam maiores do que nas atividades agrícolas (ver REARDON, 1999). Conforme foi ressaltado anteriormente, o desempenho educacional das pessoas e as condições socioeconômicas da localidade onde elas residem são considerados condicionantes importantíssimos para a obtenção de empregos com melhores salários no setor industrial e no de serviços, e para a realização e o sucesso de atividades não-agrícolas em empreendimentos outrora voltados apenas à produção de bens primários. Nesse sentido, a presença das atividades não-agrícolas tenderia a contribuir claramente para a redução da influência do capital físico e o aumento do efeito da educação na renda rural do Brasil, o que não implica negar a grande importância que a redução da concentração fundiária pode ter na diminuição das disparidades de rendimentos no setor agrícola.

De qualquer forma, os dados mostram que os estudos sobre os determinantes da desigualdade de renda rural não devem considerar apenas o setor primário. Eles devem também examinar a expansão das atividades não-agrícolas, contribuindo para a orientação de políticas mais eficazes a favor do desenvolvimento eqüitativo das áreas de baixo contingente populacional do País. Mesmo nas áreas oficialmente rurais, regiões comumente utilizadas nos estudos sobre o meio rural brasileiro, os setores secundários e terciários já representavam, no ano 2000, aproximadamente $33 \%$ de toda a renda domiciliar, um valor bastante significativo, ainda que substancialmente inferior à participação do setor primário (41,5\%). Além disso, como a razão de concentração da renda não-agrícola é bem maior do que a da agrícola, a diferença existente entre a contribuição das duas atividades para a desigualdade de renda, mesmo no rural oficial, se torna quase inexpressiva: $37,7 \%$ contra $38,6 \%$ (ver Tabela 7).

\section{CONCLUSÃo}

Nossas estimativas mostraram uma participação expressiva das atividades não-agrícolas na renda domiciliar, de 49,7\% no meio rural como um todo, 33,2\% no rural oficial, e de 63,9\% nas cidades rurais. Se, por um lado, esses valores já são suficientemente grandes para que qualquer política de distribuição de renda rural não estreite seu foco apenas no setor primário e também considere as atividades industriais e de serviços, por outro, constatamos que as atividades nãoagrícolas, em vez de contribuírem para a redução da desigualdade de renda rural, contribuem para aumentá-la.

8 Os pesquisadores costumam medir o efeito do capital físico sobre a desigualdade utilizando apenas a variável posição na ocupação. A hipótese básica é que as diferenças de acesso à propriedade estão fortemente correlacionadas com a discriminação ocupacional: empregado, autônomo e empregador (ver LANGONI, 1973). 
Foram observados dois indícios para se analisar se as atividades agrícolas e não-agrícolas contribuem para aumentar ou reduzir a desigualdade de renda rural: a participação da renda obtida em cada um dos dois tipos de atividades no rendimento total dos domicílios em diferentes estratos de renda domiciliar per capita delimitados por percentis, e a decomposição do índice de Gini. Em qualquer uma das áreas rurais definidas em nossa pesquisa, a participação da renda das atividades não-agrícolas na renda dos domicílios rurais cresce com o aumento da renda domiciliar, ao passo que a participação das atividades agrícolas diminui com o aumento da renda domiciliar. A razão de concentração da renda das ocupações não-agrícolas, por sua vez, é substancialmente maior do que o valor do índice de Gini em qualquer área rural, ao contrário das ocupações no setor agropecuário, cuja razão de concentração da renda é sempre inferior ao valor do índice de Gini.

É importante, porém, ressaltar que a contribuição de cada tipo de atividade para a desigualdade de renda rural, avaliada ao longo do artigo, procura apenas mostrar até que ponto a renda não-agrícola está mais concentrada do que a agrícola. Não são analisadas as causas da concentração de cada tipo de renda. O objetivo do artigo é chamar a atenção para que os estudos sobre os efeitos dos fatores determinantes da desigualdade de renda rural não considerem apenas o setor primário e também examinem os setores secundário e terciário. Não só na agricultura, como também nos outros setores, as famílias mais pobres, com baixo investimento em educação e que sofrem com a escassez de terra desenvolvem principalmente atividades que exigem pouca qualificação e baixo investimento, enquanto os mais ricos têm uma possibilidade bem maior de ascender às ocupações mais produtivas e bem remuneradas. É preciso desenvolver pesquisas que analisem o efeito de variáveis como educação, riqueza, localização do domicílio, discriminação por gênero e cor na conformação da renda rural, considerando todas as fontes de renda das famílias rurais.

Por fim, a maior participação das atividades RNA na renda de quem mora nas cidades rurais, se comparada à participação na renda da população oficialmente rural, ainda mostra que o uso exclusivo do critério da delimitação administrativa na definição do espaço rural oficial reduz o peso das atividades industriais e de serviços na geração de emprego e renda no meio rural do País. Com a inclusão das sedes de municípios e de distritos com baixo contingente populacional e densidade demográfica no espaço rural, o trabalho revela não só que a população rural do País é bem maior do que a oficial, como também que ela é menos agrícola. 


\section{REFERÊNCIAS}

ABRAMOVAY, R. O futuro das regiões rurais. Porto Alegre: Editora da UFRGS, 2003.

BERDEGUÉ, J. A., REARDON, T.; ESCOBAR, G. Empleo e ingreso rurales no agrícolas en América Latina y el Caribe. In: DEVELOPMENT OF THE RURAL ECONOMY AND POVERTY REDUCTION IN LATIN AMERICA AND THE CARIBBEAN. New Orleans, Louisiana, Mar., 2000.

FERREIRA, F. H. G.; LANJOUW, P. Rural non-agricultural activities and poverty in the brazilian northeast. Rio de Janeiro: PUC-RJ, 2000. (Texto para Discussão, n. 428).

GRAZIANO DA SILVA, J., MARC, J.; BIANCHINI, V. O Brasil rural precisa de uma estratégia de desenvolvimento. Brasília: CNDRS, MDA e NEAD, 2001. (Texto para Discussão, n. 2).

HOFFMANN, R. A contribuição das aposentadorias e do rendimento agrícola para a desigualdade do rendimento domiciliar per capita no Brasil. In: DIETER, W. B. e NASCIMENTO, R. (Org.). Política social preventiva: desafio para o Brasil. 1 ed. Rio de Janeiro, 2003.

. Distribuição de renda: medidas de desigualdade e pobreza. São Paulo, Editora da Universidade de São Paulo, 1998.

. Distribuição da renda no Brasil: poucos com muito e muitos com pouco. In: DOWBOR, L.; KIILSZTTAJN, S. (Org.). Economia social no Brasil. São Paulo, SENAC, 2001.

Mensuração da desigualdade e da pobreza no Brasil. In: HENRIQUES, R. (Org.). Desigualdade e pobreza no Brasil. Rio de Janeiro: Ipea, 2000.

HOFFMANN, R.; NEY, M. G. Desigualdade, escolaridade e rendimentos na agricultura, indústria e serviços, de 1992 a 2002. Economia e Sociedade, Campinas, v. 13, n. 2, jul./dez. 2004.

INSTITUTO BRASILEIRO DE GEOGRAFIA E ESTATÍSTICA - IBGE. Censo Demográfico 2000: documentação dos microdados da amostra. nov. 2002.

KAGEYAMA, A.; HOFFMANN, R. Determinantes da renda e condições de vida das famílias agrícolas no Brasil. Economia, v. 1, n. 2, jul./set. 2000.

KAKWANI, N. C. Applications of Lorenz curves in economic analysis. Econometrica, v. 45, n. 3, p. 719 727, Apr. 1977.

LANJOUW, J. O.; LANJOUW, P. Rural nonfarm employment: a survey. The World Bank, 1995. (Policy Research Working Paper, n. 1463).

LANJOUW, P. The rural non-farm sector: a note on policy options. In: WORLD BANK WORKSHOP ON NON-FARM RURAL SECTOR AND POVERTY ALLEVIATION. June 1999.

LAURENTI, A. C; DEL GROSSI, M. E. A evolução das pessoas ocupadas nas atividades agrícolas e nãoagrícolas nas áreas rurais do Brasil. In: CAMPANHOLA, C. e GRAZIANO DA SILVA, J. O novo rural brasileiro: uma análise nacional e regional. Jaguariúna: EMBRAPA, 2000.

NEY, M. G. Educação e desigualdade de renda no meio rural brasileiro. Tese (Doutorado) - $\quad$ Institutode Economia, UNICAMP, Campinas, 2006.

PYATT, G., CHEN, C.; FEI, J. The distribution of income by factor components. The Quartely Journal of Economics, v. 95, n. 3, p. 451-473, Nov. 1980.

REARDON, T., CRUZ, M. E.; BERDEGUÉ, J. Los pobres en el desarrollo del empleo rural no agrícola en América Latina: paradojas y desafíos. In: III SIMPÓSIO LATINOAMERICANO DE INVESTIGACIÓN Y EXTENSIÓN DE SISTEMAS AGROPECUÁRIOS. Centro Internacional de la Papa. Lima, Peru, 1998. 
REARDON, T. Rural nonfarm employment and incomes in Latin America: overview and policy implications. World Development, v. 29, n. 3, Mar. 2001.

. Rural non-farm income in developing countries. In: WORLD BANK WORKSHOP ON NONFARM RURAL SECTOR AND POVERTY ALLEVIATION. June 1999.

VEIGA, J. E. Cidades imaginárias: o Brasil é menos urbano do que se calcula. Campinas: Autores Associados, 2003. 